\title{
Celiac Disease Screening on Students of the Department of Nutrition and Dietetics and Medical School at Ege University
}

\section{Ege Üniversitesi Tıp Fakültesi ve Beslenme ve Diyetetik Bölümü Öğrencilerinde Çölyak Hastalığı Taraması}

\author{
Miray Karakoyun1, Recep Deviren2, Ozan Öztürk3, Rabia Etki Genç4, Sema Aydoğdu1 \\ ${ }^{1}$ Ege University Faculty of Medicine, Department of Pediatrics, Divison of Gastroenterology, Izmir, Turkey \\ 2Ege University Faculty of Medicine, Department of Pediatrics, Izmir, Turkey \\ ${ }^{3}$ Ege University Faculty of Medicine Department of Internal Medicine, Izmir, Turkey \\ ${ }^{4}$ Ege University Atatürk's School of Health, Department of Midwifery, Izmir, Turkey
}

\section{ABSTRACT}

Aim: Celiac disease is an autoimmune enteropathy which improves in genetic predisposition circumstances. Silent and atypical forms cause diagnostic problems. In this study; we aimed to improve the awareness by applying the finger prick test to the students studying in two different departments at Ege University.

Materials and Methods: We included 143 of the 173 students from Ataturk School of Health, Department of Nutrition and Dietetics in this study and 359 5th grade students in the Faculty of Medicine who were selected randomly during their practical lesson. Biocard finger prick test was applied to a total of 502 students. Students with positive results were further examined based on ESPGHAN 2012 diagnosis criteria.

Results: Of the 502 students, 259 were females $(51.5 \%)$ and 243 were males $(49.5 \%)$. The age range was $17-24$ years. Finger prick test was positive in 1 female student from the department of nutrition and dietetics (1/143), and in 3 male students from the faculty of medicine (3/359). These four students had anemia and the others were asymptomatic. One of the asymptomatic students was overweight. Routine hematological, biochemical and serological tests were performed in these four students. None of them presented isolated IgA deficiency. Anti-tissue transglutaminase, anti-gliadin and anti-endomysial antibodies were positive. Duodenal endoscopy revealed mucosal damage in these four students. Histopathological examinations were found to be compatible
ÖZET

Amaç: Çölyak hastalığl; genetik yatkınlık zemininde gelişen otoimmün bir enteropatidir. Sessiz ve atipik formları ciddi tanısal sorunlar yaratmaktadır. Bu çalışmada Ege Üniversitesi'nin 2 ayrı öğretim alanında öğrencilere temel bilgiler aktarııp ardından parmak ucu tarama testi uygulanarak farkındalığın arttırılması amaçlanmışıı.

Gereç ve Yöntem: Çalışmaya Ege Üniversitesi Atatürk Sağlık Yüksek Okulu Beslenme ve Diyetetik Bölümü'nde eğitim gören 170 öğrenciden ulaşlabilen $143^{\prime}$ ü ve tıp fakültesi 5 . sınıfta rutin pratik uygulama esnasında random 359 öğrenci dahil edilmiştir. Toplam 502 öğrenciye Biocard parmak ucu tarama testi uygulanmıştır. Tarama testi pozitif çıkanlar ESPGHAN 2012 tanı kriterlerine göre değerlendirilmiştir.

Bulgular: Çalışmaya katılan, yaş dağılımı 17-24 arasında değişen 502 öğrencinin, 259'u kız $(\% 51,5)$ ve 243'ü erkekti $(\% 49,5)$. Parmak ucu testi; beslenme ve diyetetik bölümünden 1 kız öğrencide (1/143), tıp fakültesinden, tümü erkek, 3 öğrencide (3/359) pozitif bulundu. Bu öğrencilerden anemi yakınmaları olduğu saptandı. Diğerleri asemptomatikti. Asemptomatik öğrencilerden biri aşıı kiloluydu. Bu 4 öğrenciye rutin hematolojik, biyokimyasal ve serolojik testler uygulandı. Hiçbirinde izole IgA eksikliği saptanmadı. Anti doku transglutaminaz, anti gliadin ve anti endomisyum antikorları pozitif bulundu. Tümünde doudenal mukoza endoskopik olarak 


\section{ABSTRACT}

with Marsh 3 celiac disease. All patients were started on a gluten free diet.

Conclusion: In this study, after the screening test during routine practice, we found a prevalence of celiac disease of $0.8 \%$ among students of two different departments at Ege University. Of the students, $50 \%$ were asymptomatic and this finding drew attention to the silent form of the disease.

The Journal of Pediatric Research 2015;2(2):66-9

Key words: Celiac, screening, prevalance

Conflicts of Interest: The authors reported no conflict of interest related to this article.

\section{Introduction}

Celiac disease is an autoimmune disorder that is triggered by grain consumption in people sensitive to gluten found in grains and results in inflammation and damage in the small intestinal mucosa. It is one of the most prevalent diseases in the world and it mostly threatens the Caucasian race. Recent studies have shown a prevalence of one in 20-100 people of the Caucasian race $(1,2)$.

Celiac disease shows itself after the introduction of supplementary foods and is one of the most important reasons of malabsorption in childhood. Genetic and environmental factors have a combined role in the occurrence of the disease. The most significant environmental factor is grain consumption $(3,4)$. Some environmental factors such as short-term breastfeeding, infections and early introduction of supplementary foods are also considered to play a role in the pathogenesis of the disease, another factor is human histocompatibility antigens. Practically all CD patients carry HLA DQ2 and/or HLA DQ8 alleles. Therefore, people with a family history of celiac disease have a higher risk of occurrence than the normal population. One other important point regarding the pathogenesis of the disease is that it has a high rate of co-occurrence with other autoimmune conditions such as type 1 diabetes, autoimmune thyroid, and Addison's disease. The disease can occur in both sexes, but has an incidence rate twice as high in females as in males (4-8).

Although the factors triggering the occurrence of the celiac disease are not fully known, it is considered that the partially digested gluten-rich peptides transported to mucosa and perceived as antigens and presented to lymphocytes by dendritic cells initiate the autoimmune process that results in damage to the small intestinal mucosa $(9,10)$. Based on clinical findings, celiac disease can be divided into three clinical forms: typical, atypical and silent (11).

In routine clinical applications, celiac disease is diagnosed by determining the levels of $\lg A$ and $\lg G$ anti-gliadin (AGA),

\section{ÖZET}

hasarlı bulundu. Histopatolojik değerlendirmeler Marsh 3 çölyak hastalığı lehineydi. Tümüne glutensiz diyet başlandı.

Sonuç: Ege Üniversitesi'nin 2 ayrı bölümünde, ders amaçı uygulanan tarama testi sonucunda; biyopsi ile doğrulanmış çölyak hastalı̆̆ı sıkığı \%0,8 bulunmuştur. Tanı alan öğrencilerin \%50'sinin asemptomatik olması, sessiz formlara dikkat çekmektedir. The Journal of Pediatric Research 2015;2(2):66-9

Anahtar kelimeler: Çölyak, tarama, prevalans

Çıkar Çatışması: Yazarlar bu makale ile ilgili olarak herhangi bir çıkar çatışması bildirmemiştir.

anti-endomysial (EMA) and tissue transglutaminase antibodies (anti tTG), and measuring EMA levels by immunofluorescence method, and tTG antibody levels by ELISA. Anti-tTG Ig A antibody levels are measured from finger prick blood using Biocard test that is reported to have a sensitivity rate of $88 \%$ and a specificity rate of $100 \%(12-14)$.

Since celiac disease is more prevalent among those with selective IgA deficiency, IgA levels should be measured for diagnosis, as well. However, esophagogastroduodenoscopy and duodenum biopsy must be performed for the final diagnosis of the disease. The main rule to be followed after diagnosis is the removal of gluten from the diet. A rapid recovery is achieved with a gluten free diet (15-18).

\section{Materials and Methods}

A total of 143 out of 170 students of Ataturk School of Health, Department of Nutrition and Dietetics, whom we were able to we reach, and 359 students randomly selected among fifth-year seniors during routine practice in the Faculty of Medicine at Ege University were included in the study. Before the study, confirmation has been was taken from all students with a signed form.

Biocard (Ani Biotech, Finland; UK Distributor: BHR Pharmaceuticals Ltd) finger prick test was applied to a total of 502 students. Anti-tTG Ig A antibody levels were measured from finger prick blood using Biocard test (Ani Biotech, Finland; UK Distributor: BHR Pharmaceuticals Ltd) (12-14). Biocard test requires 1 drop $(10 \mu \mathrm{L})$ of blood, obtained by performing a finger prick with a sterile lancet. The drop of blood is collected in a capillary tube which is inserted into the testing tube with the reagent solution. Following the insertion of the sample strip into the test reagents, results are available after $15 \mathrm{~min}$. There are two separate indicator fields on the test strip. A test is considered positive if a line appears in the control field as well as in the test field. The line in the test field indicates that there are anti-tTG IgA antibodies present in the blood sample, while the control line indicates normal 
levels of total IgA. Students with positive results were further examined based on ESPGHAN 2012 diagnosis criteria.

Those with positive results were further examined by measuring blood count, routine biochemical values, ferritin, IgG, A, M, PZ, INR, B12, folic acid, tissue transglutaminase, anti-gliadin and anti-endomysial antibody levels by immunofluorescence method and ELISA but in the case of IgA deficiency determination, EMA, tTG Ig G were examined. Endoscopy and duodenum biopsy were performed for final diagnosis of the disease. Biopsy specimens were evaluated and classified according to Marsh classification; the participants with results compatible with celiac disease were informed, started on a gluten free diet and placed under observation.

\section{Statistical Analysis}

SPSS version 16.0 was used for all analyses.

\section{Results}

The study group consisted of 502 students with 259 females $(51.5 \%)$ and 243 males (49.5\%) with an age range of 17-24. The participants from the department of nutrition and dietetics consisted of 116 females (81.1\%) and 27 males $(18.9 \%)$. Finger prick test gave positive results in 1 female student from the department of nutrition and dietetics (1/143), and 3 male students from the faculty of medicine (3/359). Two of these students were reported to have had anemia in childhood, and the other two students were asymptomatic. One of the asymptomatic students was overweight. These four students underwent routine hematological, biochemical and serological tests. None of them presented isolated IgA deficiency. Anti-tissue transglutaminase values were found as $72,100,106$, and 125 , respectively. Anti-gliadin and anti-endomysial antibodies were found positive in all of them. Iron deficiency was found in three students. In one student, iron deficiency was accompanied by B12 and folic acid deficiencies. Thyroid function tests were normal for all of them. Two male students were observed to have osteoporosis. Duodenal mucosa was endoscopically observed to be damaged in all of them. Histopathological examinations indicated Marsh III celiac disease. Characteristics of the patients with positive celiac serologic markers showed in Table I. All were started on a gluten free diet. The overweight student reached a normal weight in the following 3 months. Further

\begin{tabular}{|c|c|c|c|c|c|c|}
\hline & Gender & Age & Anti tTG & EMA & Ferritin & $\begin{array}{l}\text { Marsh } \\
\text { Classification }\end{array}$ \\
\hline 1 & Female & 21 & 72 & +++ & 14 & III \\
\hline 2 & Male & 22 & 100 & ++++ & 3.2 & III \\
\hline 3 & Male & 22 & 106 & +++ & 6.1 & III \\
\hline 4 & Male & 22 & 125 & ++++ & 7.3 & III \\
\hline
\end{tabular}

EMA: anti-endomysial antibody, Anti tTG: Anti-transglutaminase antibody supplementation was made for biochemical deficiencies that were not replaced in the first 3 months.

\section{Discussion}

Until recent years, it was considered that celiac disease was not fully recognized and its prevalence was unknown. However, simple and non-invasive tests have been started to be used with recent studies, and analyses revealed a large group of celiac patients. The serologic celiac disease prevalence in the world was found to range between 0.3-5\%.

Disease prevalence has been rapidly increasing and several serological screening studies from Europe, South America, Australia and the USA have shown a prevalence of up to $0.5-1 \%$ with the disease affecting both children and adults equally (19). In our screening study, we found a prevalence of celiac disease of 1:125. Dalgic et al. found a higher prevalence of celiac disease of 1:110 in a screening study conducted with 20.190 students in schools in different regions of Turkey (2). Ertekin et al. found a prevalence of 1:115 in a study conducted in and around Erzurum Province in Turkey (9), and a prevalence of 1:100 in another adult screening study conducted in Turkey (10). Similar studies have been conducted and similar prevalence rates have been reported in Europe as well. Maki et al. found a prevalence of 1:99 in a study they conducted in Finland and attributed this result to the fact that the population are genetically at risk (20). A study conducted in America with a study group of 7798 people aged 6 and above found a prevalence of celiac disease of $1 / 141$. Results obtained in our study were compatible with the literature (21).

Using a finger prick-based kit (Biocard) is a feasible method for first and second degree relatives of $C D$ patients. A recent study validating this test has demonstrated sensitivity and specificity comparable to those of conventional serological coeliac screening. This test has been specifically designed for use by non-professionals and has already demonstrated high efficacy in clinical settings. Nemec et al. found Biocard test $83.6 \%$ sensitivity and $90 \%$ specificity (22). Singh et al. found that the blood drop-based assay testing IgA antibodies was positive in 46 of 51 (sensitivity 90.2\%), and since three of the five patients testing negative had total IgA deficiency, the sensitivity value could be increased to $95.8 \%$ (23). But the studies related to biocard test are still inadequate.

The most significant problem related to celiac disease for our country is that only 10.000 to 12.000 patients have been diagnosed with it although 500.000 people are estimated to have this disease. Approximately 490.000 patients are waiting for diagnosis. Celiac disease may not always show itself with a typical pattern, it may also follow an atypical or silent course. In order to put a diagnosis to these patients, the disease must be known and clues must be sought (3).

Therefore, Celiac Disease should be taught in detail in elementary schools, high schools and universities, 
especially in university departments on human health such as medicine, dentistry, nutrition and dietetics, and psychology. Moreover, seminars should be organized and people must be enlightened through media organs in order to raise awareness for celiac disease.

\section{References}

1. Rubio-Tapia A, Hill ID, Kelly CP, Calderwood AH, Murray JA; American College of Gastroenterology. ACG clinical guidelines: diagnosis and management of celiac disease. Am J Gastroenterol 2013; 108:656-76.

2. Dalgic B, Sari $S$, Basturk B, et al. Prevalence of celiac disease in healthy Turkish school children. Am J Gastroenterol 2011; 106:1512-7.

3. Aydogdu S, Midyat L, Cakir M, et al. Long-term effect of gluten-free diet on growth velocity in Turkish children with celiac disease. Dig Dis Sci 2009; 54:2183-7.

4. Lohi S, Mustalahti K, Kaukinen K, et al. Increasing prevalence of celiac disease over time. Aliment Pharmacol Ther 2007; 26:1217-25.

5. Jones R, Sleet S. Coeliac disease. BMJ 2009; 338:3058.

6. Bardella MT, Elli L, Velio P, Fredella C, Prampolini L, Cesana $B$. Silent celiac disease is frequent in the siblings of newly diagnosed celiac patients. Digestion 2007; 75:182-7.

7. Bhattacharya M, Dubey AP, Mathur NB. Prevalence of celiac disease in north Indian children. Indian Pediatr 2009; 46:415-7.

8. Fasano A, Berti I, Gerarduzzi T, et al. Prevalence of celiac disease in at-risk and not-at-risk groups in the United States: a large multicenter study. Arch Intern Med 2003; 163:286-92.

9. Ertekin V, Selimoglu MA, Kardas F, Aktaş E. Prevalence of celiac disease in Turkish children. J Clin Gastroenterol 2005; 39:689-91.

10. Gursoy S, Guven K, Simsek T, et al. The prevalence of unrecognized adult celiac disease in Central Anatolia. J Clin Gastroenterol 2005; 39:508-11.

11. Tatar G, Elsurer $R$, Simsek $H$, et al. Screening of tissue transglutaminase antibody in healthy blood donors for celiac disease screening in the Turkish population. Dig Dis Sci 2004; 49:1479-84.
12. Toftedal P, Nielsen C, Madsen JT, Titlestad K, Husby S, Lillevang ST. Positive predictive value of serological diagnostic measures in celiac disease. Clin Chem Lab Med 2010; 48:685-91.

13. Bardella MT, Trovato C, Cesana BM, Pagliari C, Gebbia C, Peracchi M. Serological markers for coeliac disease: is it time to change? Dig Liver Dis 2001; 33:42-31.

14. Lock RJ, Stevens S, Pitcher MC, Unsworth DJ. Is immunoglobulin A anti-tissue transglutaminase antibody a reliable serological marker of coeliac disease? Eur J Gastroenterol Hepatol 2004; 16:467-70.

15. Balcı TA, Koç ZP, Mitil HA. Bone mineral densitometry findings of children with newly diagnosed celiac disease. Mol Imaging Radionucl Ther 2011; 20:59-62.

16. Hopper AD, Hadjivassiliou M, Hurlstone DP, et al. What is the role of serologic testing in celiac disease? A prospective, biopsy confirmed study with economic analysis. Clin Gastroenterol Hepatol 2008; 6:314-20.

17. Donaldson MR, Book LS, Leiferman KM, Zone JJ, Neuhausen SL. Strongly positive tissue transglutaminase antibodies are associated with Marsh 3 histopathology in adult and pediatric celiac disease. J Clin Gastroenterol 2008; 42:256-60.

18. Leffler DA, Edwards George JB, Dennis M, Cook EF, Schuppan D, Kelly CP. A prospective comparative study of five measures of gluten-free diet adherence in adults with celiac disease. Aliment Pharmacol Ther 2007; 26:1227-35.

19. Bingley PJ, Williams AJ, Norcross AJ,et al. Undiagnosed coeliac disease at age seven: population based prospective birth cohort study. BMJ 2004; 328:322-3.

20. Maki M, Mustalathi K, Kokkonen J, et al. Prevalence of celiac disease among children in Finland. $N$ Engl $\mathrm{J}$ Med 2003; 19:2517-24

21. Rubio-Tapia A, Ludvigsson JF, Brantner TL, Murray JA, Everhart JE. The prevalence of celiac disease in the United States. Am J Gastroenterol 2012; 107:1538-44.

22. Singh P, Wadhwa N, Chaturverdi MK, et al. Validation of pointof-care testing for coeliac disease in children in a tertiary hospital in north India. Arch Dis Child 2014; 99:1004-8.

23. Nemec G, Ventura A, Stefano M, et al.Looking for celiac disease: diagnostic accuracy of two rapid commercial assays. Am J Gastroenterology 2006; 101:1597-600. 